UDC 141.319.8:003.322

\author{
V. V. LIAKH ${ }^{1 *}$, M. V. LUKASHENKO²* \\ ${ }^{1 *} \mathrm{H}$. Skovoroda Institute of Philosophy, the National Academy of Sciences of Ukraine (Kyiv, Ukraine), e-mail \\ vvlvv2012@ukr.net, ORCID 0000-0003-4683-0838 \\ ${ }^{2 *}$ Vasyl' Stus Donetsk National University (Vinnytsia, Ukraine), e-mail marina.look@gmail.com, ORCID 0000-0001-5430-0808
}

\title{
PHILOSOPHICAL ANALYSIS OF A PERSON'S SELF-REFLECTION IN THE CONTEXT OF INTERNAL DIALOGUE (BASED ON "THE DISPUTE OF A MAN WITH HIS BA")
}

Purpose. The study is aimed at considering self-reflection through an analysis of the features of internal dialogue in ancient texts (XXII-XXI centuries BC) in order to identify signs of human's mythological and philosophical thinking. Theoretical basis of the work is the contemplation of a person's self-reflection in the context of his internal dialogue, through which his own human existence, his subjective and creative comprehension of the world manifest. New meanings are created and shared with others in this mental space, in particular, in crisis periods of personal and social life. Therefore, the ancient Egyptian vision of man's nature, consciousnesses and dialogism of the Self is viewed through the prism of modern philosophical concepts and as the basis for the emergence of a philosophical worldview itself. Originality. The analysis from the viewpoint of the philosophical anthropology in the text "The Dispute of a Man with His Ba" showed the opportunity of considering it not only in the context of internal dialogue, but also as a confirmed internal dialogue, which expresses itself in external speech. Comparing the mythical thinking of a man in his cohesiveness with others and the philosophical thinking of a dialogical Self, the authors come to the conclusion that it is necessary to distinguish between internal dialogues with oneself and with the introjects of others, which can be either Double or Interlocutor. It has been revealed that internal dialogues in ancient times played an important role both in structuring social chaos and in overcoming personal crisis states (from existential to clinical states of altered consciousness). This is precisely from such self-reflection that philosophy emerges as a certain discourse and a new type of thinking. Conclusions. The analysis of the text "The Dispute of a Man with His Ba" speaks about the emergence of philosophical discourse in the XXII-XXI centuries BC, on the basis of which we can conclude concerning the earlier, in comparison with K. Jaspers's definition, the transition of mankind from the cognitive revolution to a new phase of the development.

Keywords: self-reflection; internal dialogue; philosophical type of thinking; "Axial Age"; crisis states; Ba; Interlocutor; dialogical Self

\section{Introduction}

The question of man's attainment of "true self-consciousness" was considered by K. Jaspers (1949) as one of the criteria for determining the Axial Age of history, to which all ancient cultures seemed to be hidden under a veil of otherness (Jaspers, 1994, p. 37). That is, in the period between 800 and 200 years BC a man became what he is today, it was then seemingly human being to be formed and manifested. Or, as the philosopher wrote in "The Meaning and Purpose of History", the presence of such earlier works of the II-III millennium BC, which we have nowadays "A Debate Between a Man Tired of Life and His Soul" (German version of the title of the work), the Babylonian penitential psalms, the epic of Gilgamesh, etc., do not change the general evaluation of the world history, because they did not have a significant influence on the transformation of human consciousness. However, today researchers are questioning the expediency in the accentuation of Axial Age as a common root of modern civilizations, namely as a demythologizing revolution that caused changes in human consciousness and perception of their existence. In particular, they point out that such an approach appears as the creation of another myth (Smith, 2015). Therefore, in our opinion, it is worth considering the features of 
human self-reflection to the Axial Age (XXII-XXI centuries BC) through the criteria defined by K. Jaspers (1994), namely: awareness of human existence as a whole, himself and boundaries of his existence (p. 33) on the example of "The Dispute of a Man with His Ba".

This ancient Egyptian text was written in the form of an internal dialogue, which appears as part of the inner nature of a man, and which repeatedly manifested itself in philosophical texts and became the subject of scientific research. However, its philosophical and anthropological analysis in terms of reducing the frequency of using the method of introspection in modern philosophy has both theoretical and practical significance. In particular, to understand human self-consciousness, altered mental states, communicative competence of a person, coping strategies to overcome difficult life circumstances, etc. Consideration of features of the internal dialogue of a man in external speech, who lived more than 4 thousand years ago, will clarify the vision of the dialogic structure of "Self" of a man (G. Hermans), the multiplicity of consciousness through the prism of the artistic image in his inner world (M. Bakhtin) by searching for own life position (W. Bibler). Exactly in such context one of the oldest texts, survived to the present day - "The Dispute of a Man with His Ba" - has not yet been considered in the scientific literature. Both intra-personal communication and philosophical self-reflection were recorded in it.

Ancient Egyptian text, other versions in the translation of the title: "The Man Who Was Tired of Life", "The Dialogue of a Man and His Ba (or Soul)" is almost the only philosophical work among the written artifacts of Ancient Egypt and the only one written in the form of a dialogue between man and his Ba (Endel, 2001, p. 3). It is a dialogue of a disappointed man who thinks about death. It was written in the acute time of social transformations of the First Transition Period when there was the origin of the literature of pessimism; A. Erman - the researchertranslator of this text - defined this in the XIX century. Research devoted to "The Dispute of a Man with His Ba" began after its acquisition by the Royal Prussian Museum in 1843 at Sotheby's (Papyrus Berlin 3024) and continues to this day. So, until recently it was believed that we had received an incomplete text without a beginning, written in hieratic script. However, in 2003 R. Parkinson identified Papyrus Amherst III as a fragment of the Papyrus Berlin 3024, and in 2015 M. Escolano-Poveda (2017) found another missing fragment of it in the Museum Biblic of Mallorca (Spain) (p. 16). Today this work is the object of study for researchers in various fields of science (S. Akimov, A. Bolshakov, M. Lutsyuk, S. Spirina, V. Furkalo, M. Endel, J. P. Allen, J. Assmann, Y. Chobanov, M. Escolano-Poveda, B. Ouellet, R. B. Parkinson, and L. Baylis, D. Trimijopulos, S. Vittori, L. V. Žabkar, etc.), it will help to actualize its philosophical and anthropological reception.

\section{Purpose}

Respectively, the purpose of this work is to conduct a philosophical and anthropological analysis of human self-reflection in the context of his internal dialogue on the example of the ancient Egyptian text "The Dispute of a Man with His Ba". To achieve this purpose it is necessary to perform the following objectives: 1) to consider the ideas of the ancient Egyptians about human nature, its constructs; 2) to describe in consonance with them the types of internal dialogue and its goal; 3) to identify the features of self-reflection associated with the emergence of a philosophical type of thinking. 


\section{Statement of basic materials}

Appealing to the "The Dispute of a Man with His Ba", which is a recorded externalized internal dialogue of an ancient man, is attributable to the possibility of philosophical and anthropological comparison of the internal dialogue of a man in different historical epochs, in particular in the context of "Axial Age". K. Jaspers (1994), defining the state of consciousness of a man in Axial Age, emphasized that he through reflection realizes the horror of life and his own helplessness, "standing over the abyss, raises radical questions, demands liberation and salvation", "understanding his own boundaries, he sets himself higher aims, cognizes absoluteness in the depths of self-consciousness and in the clarity of the transcendent world" (p. 33). In the writing "On the Meaning of History", K. Jaspers (1996) noted that "man seeks and finds himself through questions and answers, which we name philosophizing" (p. 194).

Thus, we are talking about the fact that in ancient times the human consciousness began to realize its own self-awareness. However, such a restructuring of consciousness also caused great concern, because these were changes bordering on spiritual chaos, attempts to overcome this chaos were embodied in the formation of new world religions, philosophical and ethical categories of thought, which still largely determine people's lives. Simultaneously, the calm stability of the mythological time receded into the past, the struggle of various types of rationality began, in particular, the logos against the myth, enhancing the ethical side of religion and leaving the myth as a background.

Therefore, we took into account the hypotheses of identity and nonidentity of modern and ancient consciousness. Based on the content and form of a selected text, we assume, the author has both an internal dialogue in internal speech and internal dialogue in external speech. According to the views of the ancient Egyptians on human nature, its essences are naming (Ren), body (Sah), shadow (Shuyet), heart (Ib), spirit (Akh), soul (Ba) and double (Ka). In such a case, understanding the vision of these personal constructs corresponds to the position of M. Bakhtin, who analyzed the author's consciousness not as a form of one "Self", but as the interaction of many consciousnesses. Not the coexistence of images of many people in the light of one consciousness, but emphasizing their adequacy and equality, it is consistent with the modern studies of Meijers and Hermans:

The composite concept 'dialogical self' transcends this dichotomy by

bringing the external to the internal and, in reverse, transporting the in-

ternal to the external. This allows people to study the self as a society of

'I-positions' and, on the other hand, to consider society as populated,

stimulated, and renewed by the selves of its individual participants. In

this way, the Theory abandons any self-society dualism and any concep-

tion that regards the self as essentialized and encapsulated in and of itself.

(Meijers, \& Hermans, 2017, p. 7) 
Since internal dialogues differ with respect to whom the person is addressing, intrapersonal communication can be combined into two groups: dialogue with oneself and introject of another person. In our opinion, conversations with $\mathrm{Ba}$ and Ka correspond to them, on which we will focus on.

Let us consider the first type of dialogue, which manifests an awareness of oneself and their own boundaries and life in general. $\mathrm{Ba}$ is an internal interlocutor who can be seen as the embodiment of the contradiction that exists within the thinking person (Bolshakov, 2001). As a representative of the plan of God that is associated with a man, he cares about his afterlife rather than his earthly life (Spirina, 2006, p. 140). As conscience, intellectual ability (Hays, 2015, p. 77). Or as an entity, a component of the living, separated by death and depicted as a falcon with a human head (Endel, 2001). As a state available after death, which a Wiseman can cause while he is still alive, if he encounters a difficult situation to solve (Chobanov, 2015, p. 92). As an inner force that manifests itself in states of altered consciousness under the influence of illness, stress, or alcohol (Žabkar, 1968, p. 118). Ba is that integral human individuality, the inner invisible characteristic, which can be described only in words but is not characterized by images. Even more, words create the world of $\mathrm{Ba}$, but not describe, because the essentially nonpictorial Ba belongs to transcendental otherness (Bolshakov, 2001, p. 152). J. Assmann (1998) connects the meaning of the Egyptian word "Ba" with "manifestation" (for example, the concept of God), emphasizing that it is exclusively and unambiguously connected with the paradigm of manifestation of latent force that animates (p. 138).

Thus, $\mathrm{Ba}$ is intrinsically connected with a man but is not a man himself. This is the existential Self, which determines the awareness of the meaning and significance of being in extreme life situations, therefore it may have a different opinion that is different from everyday one. In line with the visions of ancient Egyptians, he (Ba) remains in the burial chamber after man's death and at the same time has the opportunity to move freely during the day. Interestingly, in the internal dispute Ba proclaims statements that do not correspond to the generally accepted canons of that time in the vision of death and immortality. He expresses his own views, the thoughts of a man himself, who sees changes for the worse in the world. For example, $\mathrm{Ba}$ is convinced that a person's name remains after death regardless of the funeral ritual, so it is necessary to enjoy life and get rid of constant worries. On the contrary, a person believes that without proper burial his name will be lost, and the only thing he wants now is death (Vittori, 2018, p. 183). This allows some researchers to interpret human words attesting to suicidal thoughts.

However, in this case, such an understanding is not so unambiguous and convincing, because we can assume that there is a context of illness, or approaching death, which is the ultimate situation in human life. Based on the found fragments of the beginning in the text, it can be understood that we are talking about a Wiseman named Hetty (Spirina, 2006, p. 138). The text notes that this man is recovering from a serious illness, but still lying exhausted by injustice and experiencing grief from the loss of his wife and property. He is surrounded by listeners, including a woman named Anhet (Escolano-Poveda, 2017, p. 36). That is, in this way we get a framework for a confirmed internal dialogue in external speech. This, pursuant to the theological principles of dialogism and trinitarianism, emphasizes that "the confirmation of the dialogue is considered no less important than its continuation, consistent with the asymmetry of intra-trinity communication from the standpoint of ontological positioning of Persons" (Ishchuk, 2018, p. 142). Anhet is the third person to witness Hetty's dialogue with his Ba. This 
creates a situation of triple reflection when the object of meta-cognition is the process of cognition of self-knowledge.

In the mystical meeting of a man and his Ba B. Ouellet (2004, p. vi) sees ontophany, a manifestation of a holistic "Self". Action and change of styles within one text indicate the dynamics of changes in the internal state from the delirium of existential crisis to selfintegration. This contributes to the daily practice of piety both in the joys of life and after it. Therefore, a wise person, thinking about the future amenities that will be used by his $\mathrm{Ba}$ after death, strengthens them when alive (Žabkar, 1968, p. 118).

Y. Chobanov makes another hypothesis, emphasizing that this dialogue is conducted by a Wiseman who is aware of the social crisis but is not in a state of despair or on the verge of suicide. He suffers because he fears that his life is deviating, "distracted" from the principle of Maat (world order, truth, harmony, ethical norms). Such thoughts about death can deprive him of a favorable fate in the afterlife, because of this he will meet there again with death (Chobanov, 2015, p. 91). Due to the lack of social order, evil enters the world of people without hindrance, filling it: "Brothers are malicious. We, though friends, despise each other", "Loose hearts", "Well neglected. Rage has captured everyone", "We reconciled with evil. Good is neglected everywhere", "In despair a man because of evil is unkind. But everyone is only laughed at by terrible villainies" and others. Accordingly, until a person gets rid of it, Ba will "distract" him. Therefore, it is necessary to find a way out of the vicious circle. For the disappointed, it is a variant of confession, an attempt to acknowledge, name the problem and cleanse oneself of it by turning inward, through internal dialogue with one's Ba. He must take on the pain and overcome the evil.

This aim of internal dialogue reminds P. Feyerabend's ideas about the anarchist theory of cognition. Conforming to it, the ancient Egyptian Wiseman from a new angle is looking for the structure in the social chaos of the crisis transition period, which he observes. He is that genius who, thanks to temporary solitude, inner dialogue, can see the structure where others see uncertainty and then convey its vision to other people in the text. It is precisely such a dialogue between the genius and his $\mathrm{Ba}$ that avoids the one-sidedness and limitation caused by feelings and what is already known, i.e. cognitive prejudices. In this context, the words of a person who expresses the despair of losing internal dialogue become clear: "It is stronger than me now. My Ba does not speak to me. It's so hard that it reminds me of someone's disdain". In M. Bakhtin's opinion, the main reason for a person's loss of himself is self-closure, separation from others. This is what happens when the bonds between the consciousness of Me and You are broken. That is, the whole content of consciousness is dialogized since internal experiences are formed in the process of "meeting" with another. This may be also related to the second group of internal dialogues, which also help to realize being, oneself, own boundaries and boundaries of the other.

The second type of conversation is an internal dialogue with an imaginary interlocutor who is different from ourselves, that is, with the image of another person. In our opinion, it can be correlated with a conversation with Ka, which is missing in the text "The Dispute of a Man with His Ba", but which is mentioned in other ancient Egyptian texts. Ka, like another interlocutor, allows a person to construct an image of another person even when he is absent, and to have an mental dialogue with him. He is a double of man, his image, which is thought by others. When someone pictured the image of another or saw it in a dream, he saw this with the inner vision of the real existing Ka of that person. After the man's death Ka does not disappear, so memories of the deceased and imaginary communication with him remain possible for a long time. Ka doesn't 
die while a man is remembering. To stop the time of oblivion, the ancient Egyptians mummified bodies, made their images and illustrations in the form of pictures of future life. Everyone who remembered the deceased became involved in the sacred ritual.

A. Bolshakov's book "Man and His Double" (2001) is a work in which the existing views on Ka were systematized and the common in the vision of the most respected researchers was highlighted. The above analysis provides a theoretical basis for understanding the features of internal dialogues with the introject of another. Thus, Ka is seen not as a part of a man, but as a common thing that combines the personalized "life force" of V. Christens and A. Herman, the "genius" of Steindorf, the "double" of G. Maspero and the "individuality" of A. Wiedemann. This is the holistic image of a person with his features that appear before our eyes when we remember him, looking at the portrait. The World-Double is "created" by images, but not localized in the room where they are placed. Drawings served as a stimulus to recollection, which the ancient Egyptians interpreted as "reviving" the memory of a person, as a perception of a real existing object of the external world that is in front of the eyes. It is related to the person but is not him. This is his Double.

However, the inner dispute with Ka of another person may be different. First, we can distinguish between the dialogue and metalogue from Ka: the dialogue in understanding the distribution of logos, and metalogue as a conversation with an imaginary person in order to express their own judgments and search causes and aims of the event, which is understood from the meta position. Secondly, one should distinguish between the dialogue with Ka, whom a person perceives as his own Double, and $\mathrm{Ka}$ as an Interlocutor. At self-absorption, the person will indue Ka of another man only with his own reflection, and at the attitude to the interlocutor, there is an exit in his life, constant work over himself for his sake.

If the first known artifact of the recorded philosophical metalogue is the self-reflection of the "disappointed" Hetty, the other known philosophical dialogues date back to what K. Jaspers called "Axial". This is one and a half thousand years closer to our time. Thus, the Book of Ecclesiastes also has the character of a dialogue with the interlocutor, which can be both "internal" and "external". Some of its fragments are based on the principle of quotations when the answer is given to well-known at that time ideas and do not require reference to the author. This book also contains contradictions in judgments, particularly on the subject of death.

Another, perhaps the most famous author of dialogues and the maieutic method of conversation, which helps in the birth of truth, is the ancient Greek philosopher Socrates. According to the disciples, he was accompanied since childhood by daemon - a certain embodiment of the true objective divine reality in the inner world of a man. This daemon, as the inner voice of conscience, helped him to understand complex moral and ethical situations by determining what should be avoided or what should be abandoned (this makes him partially similar to $\mathrm{Ba}$ ).

That is, our ideas of the ancient Egyptians about human nature, the conversation of the Wiseman with his own $\mathrm{Ba}$, only Gods had him according to the earlier ideas, analysis of the confirmed internal dialogue "disappointed" in external speech allows us to state that myths were already being transformed at that time, their symbolism and understanding at greater depths. This corresponds to the signs of Axial Age defined by K. Jaspers but does not coincide with its framework. The self-reflection of the "Disappointed" demonstrates the blurring of the traditional principles of life, to his anxiety about the contradictions and antinomies that arise in the process of this transition. This deep concern is conveyed in the text by a person who is not introverted, 
but who is not sure that he knows and understands himself, and therefore opens to the new and can understand what no one has questioned before, that is, to feel being, although not completely, as the question remains (Jaspers, 1994, p. 34). This is the beginning of philosophical thinking, the search for truth, seeking support within oneself, which, in the end, indicates the birth of a developed personality.

\section{Originality}

The analysis from the standpoint of philosophical anthropology in the text "The Dispute of a Man with His Ba" showed the possibility to consider it not only in the context of internal dialogue but also as a confirmed internal dialogue, which is manifested in external speech. Comparing the mythical thinking of a man in his unity with others and the philosophical thinking of the dialogical Self, the authors conclude that a distinction should be made between internal dialogues with oneself and with other people's introjects, which can be either Double or Interlocutor. It is found that internal dialogues in old times played an important role both in structuring social chaos and in overcoming personal crisis states (from existential to clinical states of altered consciousness). Exactly from such self-reflection that philosophy grows as a certain discourse and a new type of thinking.

\section{Conclusions}

The obtained results demonstrate the existence of self-reflection at the early stages of human development and, accordingly, the philosophical understanding of human existence and the realization of its search for salvation and freedom in boundary situations. It is necessary to recognize the authentic vision of dialogic Self by the ancient Egyptians, their use of the method of dialogue to overcome crisis states, structuring the situation perceived as chaos, and searching for a new vision of the world. This allows us to conclude that in the XXII-XXI centuries BC a philosophical discourse appears and the shift in human development, which K. Jaspers described as the period of "Axial Age". But in contrast to its dating to the period of "Axial Age", we must state the earlier transition of mankind to a new phase of development.

\section{REFERENCES}

Assmann, J. (1998). Mono-, Pan-, And Cosmotheism: Thinking the 'One' in Egyptian Theology. Orient, 33, 130-149. DOI: https://doi.org/10.5356/orient1960.33.130 (in English)

Bolshakov, A. O. (2001). Chelovek i ego Dvoynik. Izobrazitelnost i mirovozzrenie v Egipte Starogo tsarstva. St. Petersburg: Aleteyya. (in Russian)

Chobanov, Y. (2015). New Interpretation of "The Dialog of a man and his Ba". The Journal of Egyptological Studies, IV, 84-97. (in English)

Endel, M. (2001). Sladkiy Zapad: Predislovie k perevodu. Solnechnoe Spletenie, 14-15. (in Russian)

Escolano-Poveda, M. (2017). New Fragments of Papyrus Berlin 3024. Zeitschrift für Ägyptische Sprache und Altertumskunde, 144(1), 16-54. DOI: https://doi.org/10.1515/zaes-2017-0002 (in English)

Hays, C. B. (2015). A Covenant with Death: Death in the Iron Age II and Its Rhetorical Uses in Proto-Isaiah. Eerdmans. (in English)

Ishchuk, N. V. (2018). Suchasna pravoslavna teolohiia dialohu: Monohrafiia. Kyiv: PF «PP "Foliant"». (in Ukrainian)

Jaspers, K. (1994). Smysl i naznachenie istorii. M. Levina, Trans. from German. Moscow: Respublika. (in Russian)

Jaspers, K. (1996). Vom Sinn der Geschichte. A. Hordiienko, Trans. In V. V. Liakh, \& V. S. Pazenok, Suchasna zarubizhna filosofiia. Techii i napriamy: Khrestomatiia (pp. 184-210). Kyiv: Vakler. (in Ukrainian) 
Meijers, F., \& Hermans, H. (2017). Dialogical Self Theory in Education: An Introduction. In The Dialogical Self Theory in Education (pp. 1-17). Springer. DOI: https://doi.org/10.1007/978-3-319-62861-5_1 (in English)

Ouellet, B. (2004). Le Désillusionné et son ba du Papyrus Berlin 3024. L’herméneutique d’une expérience ontophanique. Montréal: Université de Montréal. (in French)

Smith, A. (2015). Between facts and myth: Karl Jaspers and the actuality of the axial age. International Journal of Philosophy and Theology, 76(4), 315-334. DOI: https://doi.org/10.1080/21692327.2015.1136794 (in English)

Spirina, S. A. (2006). Some aspects of translation and interpretation of "The Dispute between a Man and his Ba" (Papyrus Berlin 3024). In Drevniy Egipet. Sbornik trudov Assotsiatsii po izucheniyu Drevnego Egipta "MAAT" (pp. 137-141). (in English)

Vittori, S. (2018). Two Direct Speeches in the Last Two Poems of the 'Dialogue between a Man and His Ba' (pBerlin 3024, cc. 138-140 and cc. 144-145): A Note of Translation. Linguistics and Literature Studies, 6(4), 183-187. DOI: https://doi.org/10.13189/lls.2018.060404 (in English)

Žabkar, L. V. (1968). A Study of the Ba Concept in Ancient Egyptian Texts. The University of Chicago Press. (in English)

\section{LIST OF REFERENCE LINKS}

Assmann J. Mono-, Pan-, and Cosmotheism: Thinking the 'One' in Egyptian Theology. Orient. 1998. Vol. 33. P. 130-149. DOI: https://doi.org/10.5356/orient1960.33.130

Большаков А. О. Человек и его Двойник. Изобразительность и мировоззрение в Египте Старого иарства. Санкт-Петербург : Алетейя, 2001. 288 с.

Chobanov Y. A New Interpretation of "The Dialog of a man and his Ba". The Journal of Egyptological Studies. 2015. № IV. P. 84-97.

Эндель М. Сладкий Запад : предисловие к переводу. Солнечное сплетение. 2001. № 14-15.

Escolano-Poveda M. New Fragments of Papyrus Berlin 3024. Zeitschrift für Ägyptische Sprache und Altertumskunde. 2017. Vol. 144. Iss. 1. P. 16-54. DOI: https://doi.org/10.1515/zaes-2017-0002

Hays C. B. A Covenant with Death: Death in the Iron Age II and Its Rhetorical Uses in Proto-Isaiah. Eerdmans, 2015. $465 \mathrm{p}$.

Іщук Н. В. Сучасна православна теологія діалогу : монографія. Київ : ПФ «ПП "Фоліант"», 2018. 304 с.

Ясперс К. Смысл и назначение истории / пер. с нем. М. Левиной. Москва : Республика, 1994. 527 с.

Ясперс К. Про сенс історії / пер. А. Гордієнка. Сучасна зарубіжна філософія. Течії і напрями : хрестоматія / упоряд. В. В. Лях, В. С. Пазенок. Київ : Ваклер, 1996. С. 184-210.

Meijers F., Hermans H. Dialogical Self Theory in Education: An Introduction. The Dialogical Self Theory in Education. Springer, 2017. P. 1-17. DOI: https://doi.org/10.1007/978-3-319-62861-5_1

Ouellet B. Le Désillusionné et son ba du Papyrus Berlin 3024. L'herméneutique d'une expérience ontophanique. Montréal : Université de Montréal, 2004. 328 p.

Smith A. Between facts and myth: Karl Jaspers and the actuality of the axial age. International Journal of Philosophy and Theology. 2015. Vol. 76. Iss. 4. P. 315-334. DOI: https://doi.org/10.1080/ 21692327.2015.1136794

Spirina S. A. Some aspects of translation and interpretation of "The Dispute between a Man and his Ba" (Papyrus Berlin 3024). Древний Египет. Сборник трудов Ассочиации по изучению Древнего Египта "МАAT". 2006. C. 137-141.

Vittori S. Two Direct Speeches in the Last Two Poems of the 'Dialogue between a Man and His Ba' (pBerlin 3024, cc. 138-140 and cc. 144-145): A Note of Translation. Linguistics and Literature Studies. 2018. Vol. 6. Iss. 4. P. 183-187. DOI: https://doi.org/10.13189/lls.2018.060404

Žabkar L. V. A Study of the Ba Concept in Ancient Egyptian Texts. The University of Chicago Press, 1968. 163 p.

\section{В. В. ЛЯХ ${ }^{1^{*}}$, М. В. ЛУКАШЕНКО ${ }^{2 *}$}

\footnotetext{
${ }^{1 *}$ Інститут філософії імені Г. С. Сковороди, Національна академія наук України (Київ, Україна), ел. пошта vvlvv2012@ukr.net, ORCID 0000-0003-4683-0838

2* Донецький національний університет імені Василя Стуса (Вінниця, Україна), ел. пошта marina.look@gmail.com, ORCID 0000-0001-5430-0808
} 


\section{ФІЛОСОФСЬКИЙ АНАЛІЗ САМОРЕФЛЕКСІї ЛЮДИНИ В КОНТЕКСТІ ЇЇ ВНУТРІШНЬОГО ДІАЛОГУ (НА ПРИКЛАДІ "РОЗМОВИ РОЗЧАРОВАНОГО ЗІ СВОЇМ БА")}

Мета. Дослідження спрямовано на осмислення саморефлексії крізь аналіз особливостей внутрішнього діалогу в давніх текстах (XXII-XXI ст. до н. е.) з метою вияву ознак міфологічного і філософського мислення людини. Теоретичним базисом роботи є розгляд саморефлексії людини в контексті ії внутрішнього діалогу, крізь який проявляється власне людське буття, ії суб’єктивно-творче осмислення світу. В цьому ментальному просторі відбувається творення нових смислів та поділення ними з іншими людьми, зокрема, в кризові періоди особистісного і соціального життя. Відтак давньоєгипетське бачення природи людини, iї свідомостей та діалогічності Я розглядається крізь призму сучасних філософських концепцій та як підгрунтя виникнення власне філософського світогляду. Наукова новизна. Аналіз з позиції філософської антропології тексту "Розмова розчарованого зі своїм Ба" засвідчив можливість розглянути його не лише в контексті внутрішнього діалогу, а і як підтверджений внутрішній діалог, що проявляється у зовнішньому мовленні. Зіставляючи міфічне мислення людини в її єдності з іншими та філософське мислення діалогічного Я, автори доходять висновку, що слід розрізняти внутрішні діалоги із самим собою та з інтроектами інших людей, які можуть бути або Двійником, або Співрозмовником. Виявлено, що внутрішні діалоги вже в давні часи виконували важливу роль як у структуруванні соціального хаосу, так і в подоланні особистісних кризових станів (від екзистенційних до клінічних станів зміненої свідомості). Саме з такої саморефлексії виростає філософія як певний дискурс і новий тип мислення. Висновки. Проведений аналіз тексту "Розмови розчарованого зі своїм Ба" свідчить про появу філософського дискурсу в XXII-XXI ст. до н. е., на підставі чого можна зробити висновок про більш ранній, порівняно з визначеним К. Ясперсом, перехід людства від когнітивної революції до нової фази розвитку.

Ключові слова: саморефлексія; внутрішній діалог; філософський тип мислення; "осьовий час"; кризові стани; Ба; Співрозмовник; діалогічне Я

\section{В. В. ЛЯХ ${ }^{1^{*}}$, М. В. ЛУКАШЕНКО ${ }^{2 *}$}

\footnotetext{
${ }^{1 *}$ Институт философии имени Г. С. Сковороды, Национальная академия наук Украины (Киев, Украина), эл. почта vvlvv2012@ukr.net, ORCID 0000-0003-4683-0838

$2^{2 *}$ Донецкий национальный университет имени Василия Стуса (Винница, Украина), эл. почта marina.look@gmail.com, ORCID 0000-0001-5430-0808
}

\section{ФИЛОСОФСКИЙ АНАЛИЗ САМОРЕФЛЕКСИИ ЧЕЛОВЕКА В КОНТЕКСТЕ ЕГО ВНУТРЕННЕГО ДИАЛОГА (НА ПРИМЕРЕ "РАЗГОВОРА РАЗОЧАРОВАННОГО СО СВОИМ БА")}

Цель. Исследование направлено на рассмотрение саморефлексии через анализ особенностей внутреннего диалога в древних текстах (XXII-XXI ст. до н. э.) с целью выявления признаков мифологического и философского мышления человека. Теоретическим базисом работы есть рассмотрение саморефлексии человека в контексте его внутреннего диалога, через который проявляется собственно человеческое бытие, его субъективно-творческое осмысление мира. В этом поле происходит создание новых смыслов и их разделение с другими, в частности, в кризисные периоды личной и социальной жизни. Так, древнеегипетское видение природы человека, его сознаний и диалогичности Я рассматривается сквозь призму современных философских концепций и как основа возникновения собственно философского мировоззрения. Научная новизна. Анализ с позиции философской антропологии текста "Разговора разочарованного со своим Ба" свидетельствует о возможности рассматривать его не только в контексте внутреннего диалога, но и как подтверждённый внутренний диалог, который проявляется во внешней речи. Сопоставляя мифическое мышления человека в его единстве с другими и философское мышление диалогического Я, авторы приходят к выводу, что следует отличать внутренние диалоги с самим собой и с интроэктами других, которые могут быть или Двойником, или Собеседником. Выявлено, что внутренние диалоги уже в древние времена выполняли важную роль как в структурировании социального хаоса, так и в преодолении личностных кризисных 
состояний (от экзистенциальных до клинических состояний изменённого сознания). Именно из такой саморефлексии вырастает философия как определённый дискурс и новый тип мышления. Выводы. Проведённый анализ текста "Разговора разочарованного со своим Ба" свидетельствует о появлении философского дискурса в XXII-XXI в. до н. э., что является более ранним, по сравнению с определённым К. Ясперсом, переходом человечества от когнитивной революции к новой фазе развития.

Ключевые слова: саморефлексия; внутренний диалог; философский тип мышления; "осевое время"; кризисные состояния; Ба; Собеседник; диалогическое Я

Received: 16.12 .2019

Accepted: 08.05.2020 